\title{
POETRY AS AN ELEMENT OF THE APARTHEID MILITARY DISCOURSE
}

\author{
Andre van der Bijl $1^{1}$ \\ Cape Peninsula University of Technology
}

\begin{abstract}
From the 1970 s to the early 1990 s, 'struggle poetry' served to define elements of the struggle against apartheid. In contrast to struggle literature, which was open and clearly focussed, pro-apartheid literature was not produced in abundance and, when it appeared, was shrouded in social discourse, including historical analysis, terminology, the articulation of specific viewpoints, humour and a sense of duty. One of the longest-lasting windows into apartheid military propaganda was Peter Badcock's Images of war (1981), a compilation of pencil sketches and short poetic works that used simple blank verse and images of racial diversity, romance and implied tradition. ${ }^{2}$ This article presents a discourse analysis of the above-mentioned publication, using both Foucault-infused thoughts ${ }^{3}$ and a critical discourse analysis methodology developed by Fairclough. ${ }^{4}$ It provides insight into how the apparatus of a state can gain popular support for sociologically unacceptable practices. Understanding the latter contributes to an understanding of power relations and ideological processes that underlie text and rhetoric.
\end{abstract}

\section{Introduction}

From the 1970 s to the early 1990 s, one particular form of visual and literary arts in South Africa flourished, largely as an active resource in the anti-apartheid struggle. The works of art, which included two- and three-dimensional graphic art, novels and poetry, were presented in both the mainstream and alternate forums ${ }^{5}$ with levels of quality that produced university graduates and staff, as well as positive international responses.

What has become known as 'struggle poetry' served to define elements of the struggle against apartheid through dissemination and publication. The nature

Scientia Militaria, South African Journal of Military Studies, Vol 39, Nr 1, 2011, pp. 56-84. doi:

$10.5787 / 39-1-102$ and size of poetry not only made it easy to disseminate at, for example, so-called illegal gatherings, but also resulted in vibrant music and publication practices. The developers of such material, however, risked life and limb 
for the practice of their trade or art form. The state counteracted these practices with violence and legal processes, which included censorship, banning and imprisonment for content developers.

In contrast to struggle literature, which was abundant, open and clearly focussed, pro-apartheid literature was not produced in abundance and, when it appeared, was shrouded in social discourse, including historical analysis, terminology, the articulation of specific viewpoints, humour and a sense of duty (see numerous examples by W. Steenkamp and A.J. Venter, as well as publications by De Vries, Gee, Grobler and Retief). ${ }^{6}$ While clarity framed the spearhead of the antiapartheid information war, fog was the pro-apartheid defence.

Probably the clearest and longest-lasting illustrations of the nature of the fog, and a window into the nature of apartheid propaganda around which the apartheid military success was built, was Peter Badcock's Images of war. Badcock's Images of war is a compilation of pencil sketches and short poetic works, mainly short poems in blank verse. By using simple blank verse and images of racial diversity, romance and implied tradition, Badcock created pictures of belonging, service, manliness and race that encapsulated their apartheid-aligned definitions.

This article proposes to present a summary of a discourse analysis of the above-mentioned publication. The analysis will make use of Foucault, ${ }^{7}$ particularly his expressions of punishment and torture, which provide a frame of reference within which crime and punishment are enforced without the use of force. Foucault's work is an expression of broad discourse analysis associated with the European post-structural paradigm. ${ }^{8}$ The tools developed in linguistic discourse analysis (see Maclure), ${ }^{9}$ which focusses on choice and meaning of words and sentences and the way in which such words and sentences have been linked, are also used. The primary analytical tool used is critical discourse analysis, as developed by Fairclough. ${ }^{10}$ A critical analysis of the discourse, the words and sentences selected and the way these have been strung together, indicate that, behind simple illustrations of tradition, duty, camaraderie and private time, lies the expression of the apartheid ideology, by alluding to values and attitudes without stating the underlying racist agenda.

Analysing and interrogating the apartheid state's strategy aimed at its support base is not only a necessary element of social transformation in South Africa; it also serves to provide insight into how the apparatus of a state can gain popular support for sociologically unacceptable practices. Understanding the latter contributes to an understanding of power relations and ideological processes that underlie text and rhetoric, which can be applied as a general analytical tool. 


\section{Analytical framework, research design and choice of data source}

Discourse analysis is a tool commonly used by language practitioners and social researchers to analyse the meanings underlying text and perceptive rules that produce meaning, form subjects and regulate conduct within particular social and historical frameworks. ${ }^{11}$ Although the terms discourse and discourse analysis are similar, they are not the same. For the purposes of this article, the term discourse is accepted to refer broadly to language use in particular institutional, social and historical circumstances. ${ }^{12}$ As language usage reflects ideological processes and power relations, the analysis of text contributes to an understanding of power relations and ideological processes in a discourse. ${ }^{13}$ In this article, Discourse, spelt with an uppercase D, is used in the European post-structural sense and refers to broad social or institutional processes that regularise conduct. ${ }^{14}$ In other cases, discourse, spelt with a lowercase $\mathrm{d}$, is used in a linguistic sense. When used in this sense, the focus is on the choice of words and paragraphs, with an emphasis on structure and meaning of texts, ${ }^{15}$ within the context in which they have been placed.

For the purposes of this article, Discourse analysis is regarded as a research tool used to describe and analyse how language produces meaning, and forms subjects and regulatory conduct. As with the derivative terms, a distinction can be made between Discourse analysis, framed within the European post-structural paradigm, and a linguistic discourse analysis. The former is largely based on ideas formulated by Foucault and presented in this article as generalised terms used to name phenomena. Linguistic discourse analysis, on the other hand, focusses on structure and meaning of text. It investigates the "rules for building extended stretches of talk or writing"16 and is based within a (structuralist) framework of knowing the grammatical parameters within which the meaning is constructed. Linguistic discourse analysis uses accepted grammatical norms as the basis for its analysis and is based on the supposition that discourse shapes and is shaped by society, ${ }^{17}$ that discourse helps to constitute knowledge, and that discourse is shaped by power struggles. This form of analysis is focussed on the relationship between language and power and is based on the argument that text analysis can contribute to an understanding of power relations and ideological processes in a discourse. ${ }^{18}$

Foucault's work has become popular to explain social use of power. Foucault provides what Deacon ${ }^{19}$ calls "an array of concepts, analytical techniques, and arguments". Foucault's Discipline and punish: The birth of the prison, first published in 1975, is particularly valuable in analysing militarisation. ${ }^{20}$ In this publication, Foucault uses the concepts of moral orthopaedics, ${ }^{21}$ body politic, ${ }^{22}$ power-knowledge $e^{23}$ and artificial order. ${ }^{24}$ Foucault also provides an argument on the replacement of an emphasis on physical punishment with the development of a system of punishment aimed at the soul. ${ }^{25}$ 
The linguistic discourse analysis-based analytical process used in this article is rooted in the process initially described by Fairclough. ${ }^{26}$ It involves a description of text, based on ten key questions, followed by an interpretation and explanation, and analysed by MR or member's resource. ${ }^{27}$ MR involves the use of an analyser's background knowledge, i.e. the general knowledge the analyst has in the area of analysis. The MR in the current analysis is primarily general knowledge gained from thirty years of involvement in the South African military, as well as social analysis applied in the business and education environments.

The findings are presented within the two discourse analysis frameworks mentioned. The initial and summative analysis of selected literature is framed within the Discourse framework, referred to as the 'apartheid Discourse' or the 'anti-apartheid Discourse' and provides general indicators of the nature of the antiapartheid/struggle strategy, as well as the broad strategies applied by the apartheid state to maintain itself.

The critical linguistic discourse framework used in the detail of the analysis of Badcock's work in this article follows the three-phase process initially suggested by Fairclough. ${ }^{28}$ The process includes description, interpretation and explanation, with the third phase reflected in this article. The explanation, however, follows a detailed analysis carried out in the analysis of vocabulary, grammar and textual structure of the earlier phases.

As the publication from which the linguistic discourse has been drawn ${ }^{29}$ is

two decades old, later publications were also used. These include Fairclough, ${ }^{30}$ Maclure $^{31}$ and Henning. ${ }^{32}$ Henning's notes on content analysis were used to contextualise the interpretation, as well as to code and label data. ${ }^{33}$ In addition, ideas generated from reading Fairclough's later publication ${ }^{34}$ and a variety of other research outputs have been used. Although Fairclough's 1989 publication is very prescriptive, it remains a simple but thorough systemic mechanism for collecting and indicating the portrayal of selected social constructs, especially when used as an indicator of language in use and not as a prescriptor.

\section{Promoting the apartheid Discourse}

The pro-apartheid Discourse, particularly in the late 1970s and early 1980s, was expressed differently at the different levels of society, with an emphasis on a dualistic, two-world approach. In black townships and rural areas, the so-called 'third world', violent repression and, as a result, violent resistance were common practice. $^{35}$ In contrast, in the urban, 'first world' environment, maintaining apartheid domination was very subtle, virtually unnoticeable.

Subjection $^{36}$, Foucault ${ }^{37}$ indicated in accounting for changing approaches to the torture of criminals, was obtained "not by instruments of violence or ideology" 
but by the "direct, physical, pitting of force against force, bearing on material elements and yet without involving violence". It was "calculated, organized, technically thought out ... subtle, make[ing] use neither of weapons nor of terror and yet remain[ing] of a physical order".

The apartheid state applied multiple and multidimensional subjugation technologies, ranging from suppression to rule of law to ideological expressions of power. At a national level, the Discourse was advanced through a parliamentary system that limited access to people legislatively classified as white until 1983, and thereafter a tri-cameral parliamentary system, for whites, coloureds and Asians, and puppet-type governments for areas designated for habitation by people whose home language was of African origin.

With the aim of maintaining the desired social structure, an extensive bureaucracy and private sector support base was developed to support the Discourse. The bureaucracy included the development of an extensive military structure based on conscription of white males and voluntary service by women and males from other race groups. The private sector support base was developed through measures ranging from an extensive system of industrial decentralisation providing incentives for the establishment of business in and around geographic areas designated for black habitation to funding, concessions and selective operation of the free market, including a programme of industrial decentralisation. ${ }^{38}$

The Discourse was not limited to state-orchestrated actions. It was supported by multiple layers of what Foucault ${ }^{39}$ called "moral orthopaedics", 40 which included publication mechanisms explaining and accounting for the required military service and all aimed at internalising national obedience.

The expression of the Discourse's expression was aimed at the population who could or would support it, commonly without regard for those who did not. The opposing Discourse was repressed, violently or by means of legal exclusion processes, including an extensive and active censorship system. Very commonly, a combination of repression mechanisms was used.

For its existing and potential support base, mainly for white South Africans, the apartheid way of life was energetically promoted positively. The war, mainly in Namibia, but increasingly in the 1980s in townships, was fought by a cohort of regular army leaders and conscripted subordinates. Publications aimed at the general public ${ }^{41}$ include fiction, ${ }^{42}$ documentary publications ${ }^{43}$ and publications of poetry, of which Peter Badcock's Images of war is probably the best known. The publications applied the use of a collection of selected facts and related emotions, each focussing on some or other element of military service.

Badcock's work, which will be analysed in detail, is particularly interesting in that it presented not only the apartheid ideology; but also provided a mirror of the apartheid Discourse and the apartheid military Discourse. It also provided an 
indication of how the apartheid view was publicised to white South Africa in the early 1980 s.

The use of poetry to express views that cannot be expressed openly for fear of reprisal, or by using dominant logic, is not unusual. World-renowned literary critic and linguist Umberto Eco noted that metaphor and oxymoron can be, and in this case are, used to express what other more common forms of communication cannot. ${ }^{44}$ Poems by people like Wilfred Owen and Siegfried Sassoon - prescribed reading in schools in many parts of the world - are evidence of how poetry is used to express an anti-war sentiment at a time when such sentiments were socially unacceptable. Some generals have also been known to use poetry to describe their work. US general George S. Patton Jr. is said to have written poems during both world wars, including one on the destruction of the town of Houffalize, which was said to follow the rhythm of the children's Christmas carol Little child of Bethlehem. $^{45}$

Oh little town of Houffalize,

How still we see thee lie;

Above thy steep and battered streets

The aeroplanes sail by.

Yet in thy dark streets shineth

Not any goddamned light;

The hopes and fears of all thy years,

Were blown to hell last night.

Houffalize was a key point in the US counteroffensive against the German army's Ardennes offensive of 1944/1945. Patton's expression of anger was allegedly a reaction to an order that forbade his divisions from entering the town until the Royal Air force had carried out a pre-attack bombardment that he felt was not necessary.

Peter Badcock's Images of war differs from works by Owen or Sassoon which were largely therapeutic works by individuals used to contribute towards the prevention of war. It also differs from Patton's practice of using verse in private documents. This publication was produced as a piece of apartheid military propaganda written by a "reserve force officer during Rhodesia's protracted struggle" whose "experience and [his] physical and emotional involvement in the country's war [was intended to] lend perspectives to Images of war". "For the reader, this implied that Badcock had the experience of the situation within which they found themselves. Regarding the apartheid state, however, Badcock undoubtedly had the experience of portraying the conflict in the light desired. Rhodesians were good at what the Rhodesian Minister of Information, PK van der Byl, in 1966 called "the propagation of the faith and belief in a particular 
ideology". ${ }^{47}$ As a Rhodesian, Badcock had been subjected to and was part of an extensive communications effort that included television documentaries, articles published in magazines in other parts of the world, novels and similar forms of poetry expressed in the publication.

Metaphor and oxymoron regarding service and the normality of military life were used as the technology to promote subjection of white males and their social support mechanism. In other words, the call to the soul (the individual's mental and psychic composition) of the masculine, rather than the expression of the more distasteful racist ideology was used to get and maintain voluntary support.

\section{Images of war by Peter Badcock}

This publication is a form of moral orthopaedics in which the reader is subjected to the idea that military service is a normal part of a process in which men are involved, as part of the pursuit of peace. It contextualises the racial nature of the war by using specific text, supported by pencil sketches, to promote the apartheid military Discourse. As will be illustrated later, coloured people are portrayed by Badcock as operationally suspect, and blacks as out of place. White males, on the other hand are portrayed as trained, professional and able to find a niche in the military environment. The apartheid ideology is reflected in the way different races and classes are placed in society. The ideology is seamlessly laced into the work by means of social, geographical and cultural metaphors. Through blank verse and associated sketches, it highlights the collective experience and knowledge base of life in the military developed by generations of military service to which South African males had been subjected. The place of war in the pursuit of peace is asserted in the final poem through the assertion that peace is the ultimate objective. ${ }^{48}$ The view of the international context, that of the Cold War and what in South Africa at the time was called the 'total onslaught', is created through implied analogy by means of including an annexure of weapons used by the South African armed forces and weapons used by those opposing them. ${ }^{49}$ The annexure has two sections, one showing a range of western/NATO weapons and locally produced weapons, while the other section illustrates and describes communist bloc weapons.

The phonology, grammar and vocabulary are either light, positive English or framed within sentences identifiable by South Africans as stereotypically characteristic of blacks, ${ }^{50}$ coloureds, ${ }^{51}$ poor whites ${ }^{52}$ and Bushmen. ${ }^{53}$

In addition to the careful use of grammar, associated graphics, in the form of pencil sketches, were used to reinforce the author's social paradigm. Graphics are used in two ways. African artefacts and geographic references, firstly, are used to paint pictures of the experiences of black Africans. Where slang is used, it is accompanied by sketches of coloureds, ${ }^{54}$ a soldier with hair longer than the accepted 
norm and torn trousers ${ }^{55}$ and a partially dressed snooker player with a bullet head for a necklace. ${ }^{56}$ Slang is used to indicate social class. Graphics, secondly, are used as an iconic reinforcement mechanism. The sketches accompanying text include a "rosary of glinting shells", 57 a "man-made butterfly"58 and "a living sculpture". 59 These illustrations show a young man surrounded by mortar bombs (the rosary), one of which he is cleaning, ${ }^{60}$ a young man putting aviation fuel into an aeroplane (the man-made butterfly) $)^{61}$ and a person peering over the top of a watch-tower constructed on top of a metal antenna mount (the living sculpture). ${ }^{62}$

\section{Portrayal of race}

The vast majority of sketches in this publication portray white male soldiers. Other races, where addressed, are portrayed as either inefficient, out of place or victims.

Two poems include sketches of what in South Africa is known as 'coloured people'. One involves soldiers complaining while on parade ${ }^{63}$ the other is linked to a person on guard duty sitting on a broken chair reading a book. ${ }^{64}$ Both poems, in very different ways, portray the perception that coloureds are lazy and inefficient. The first is written as a monologue:

Agh no man!

He talk, talk, talk, this bleddy sergeant-major.

All a' time. ${ }^{65}$

The two soldiers in the accompanying drawing appear to be unhappy, wearing headgear in a non-regulatory manner.

The following poem, ${ }^{66}$ which also has a soldier's uniform out of regulatory parameters, ${ }^{67}$ is written as a mock satire and worded as a question:

Is it perhaps the searing strength

Of D.H. Lawrence, or yet

The noble words of Shakespeare

Or science fiction, sex or socialism?

What web of imagery

Is spun about hum, this silent sentry

Lost in the pages

Of another world, far from this place

That binds him.

In the first extract, the group of soldiers are unhappy and disrespectful; in the second, the soldier is lost. Coloureds are never shown in combat, only on parade 
or on guard duty, tasks left for second-rate soldiers. In both situations, they are portrayed negatively.

Blacks are portrayed as out of place in the modern military, both in terms of the work at hand, as well as the pace required, showing them as preferring leisurely traditional rural life. One poem illustrates this. It is called "Learning the ropes" and shows a black soldier pulling himself along a rope in a river-crossing exercise. This poem is written as a reflection of life in a rural black community. Note that it is written as a series of questions, contrasting food, shade, talking, sitting, women and beer with running like animals, climbing and sweating unnaturally.

Ah when the huts are heavy

With breakfast smoke

And there is shade

Beneath the spreading tree.

Where men should sit

And talk,

Is it right I ask you

That man must run

And swing on ropes, like a young baboon,

Or crawl through dusty tunnels

Like an antbear?

Can it be so

That to make a man a soldier

He must jump and climb,

Cross pits, which are deep.

And blind himself with sweat

Which pours from him

Like summer rain

Can it be right

To do these things, when the smell

Of cooking mealies

Signals noon, and the women

Stir new beer? ${ }^{68}$

Even when blacks are placed within a martial framework, they are portrayed in a contradictory subordinate position. The word 'foreign' is used to describe the relationship between the soldiers and their white officer. One poem called "One with the shadows", ${ }^{69}$ illustrates the social context of "A Zulu soldier of the South African Army's 121 Battalion":

He slips forward, into the battle that must come, 
His officer beside him breathing orders

In a rolling of clicks, his pale blond face

Strangely foreign in the mist of impis

That swirls and melts

Behind them.

Earlier in the poem, reference is made to the Zulu ancestry by noting, "As one with his father's father, In the service of Cetshwayo". The historic contradiction is made between the soldier's current situation and of the battle in which Cetshwayao's led the Zulu army to victory over the British at Isandhlwana, and later, in 1879, to defeat at Rorke's Drift.

The placement of blacks in combat in an ambush situation does not necessarily reflect positively on the "sons of Cetshwayao's army". Like their ancestors, they are depicted as being able to "find the shadows and be one with them". ${ }^{70}$ The contradiction of the Isandhlwana analogy was crisply summarised by Montgomery:

In 1879 a British force of some 6,000 men under Lord Chelmsford was all but wiped out at Isandhlwana by a larger Zulu army, whose main body had completely concealed its presence. But later that year at Ulundi, Chelmsford avenged his defeat: the rifle was too much for the assegai.", 11

Zulus, the two texts agree, are deceptive but manageable by means of violence and discipline.

Bushmen, the Khoi-San of Southern Africa, are depicted as accepting victims of a harsh environment. A poem called "The Bushman"72 is once again written as a series of questions:

How much killing

Have my people seen?

They who ran before it, innocent of war,

Finding refuge

Through the course of time, in a thirstland home

Whose very desert promised sanctuary.

How much further can we go,

Or where?

Before the tide that breaks around us,

Engulfs us finally, leaving only

Memories

Of our passing. 
In contrast to the portrayal of blacks, a poem called "The vigil"" the portrayal of a white soldier. This poem is accompanied by a drawing of a white male beside a heavy machine gun, peering through a pair of binoculars, wearing, amongst others, a digital watch. His weapon and equipment are clean, his hair combed and his wrist-watch is the most modern available at the time. No questions are asked, each verse starts with a statement, followed by metaphoric statements about the river that separated whites from black-governed Southern Africa, the nature of the ground he was watching and the area beyond:

Sentinel

Above the wide Zambezi

That churns and tumbles past, unconcerned

By this vigil

Upon its southern shore.

Sentry

Cool, concealed

For whom the river is no joy

But instead a hostile vista,

Perhaps a killing ground,

To be monitored and measured

In a clinical and ceaseless cycle.

Sentinel

Above the southern shore,

How dark the shadows seem

Upon the northern bank.

Although all white males were required by law to serve in the South African Defence Force (SADF), life in the force was dominated by Afrikaner nationalist ideals and the Afrikaans language. The legislative reason for the existence of national service was the Nationalist Party's apartheid system with its underlying Afrikaner nationalist ideology. In line with the Afrikaner nationalist hegemony, Badcock gives the Afrikaans-speaking person a special place. The Afrikaner is linked to the conflict in terms of blood, both historically and physically. In one poem, "Boer blood" ${ }^{74}$ Badcock links the Afrikaner to Africa, through the breed of horse $^{75}$ that evolved with white colonisation, and the Afrikaner's commitment to the conflict.

The heritage of Africa

Is written in his face. 
The highveld haze in his horizon

And night is his friend.

Boer blood quickens in him:

He rides as his grandfather did

In another time.

On a horse descended,

By some quirk of fate,

From those his grandfather rode.

He is born of the land,

Knows and nurtures it

And will, if need be,

Die for it. ${ }^{76}$

The promise indicated above is confirmed later in a poem indicating a casualty. ${ }^{77}$ The casualty's surname is mentioned, namely Van Zyl, an Afrikaner name. It is also the only personalisation used in the publication.

\section{The male and the military}

The publication places the military as a natural part of life, love and entry into manhood supported by paternal figures.

The assertion that the male has a natural and historical martial role supported by "your father" 78 is conceptualised in the first and last poems; the individual poems elaborate the idea by reflecting on specific experiences.

The first poem notes, reinforcing earlier references that include pyrotechnics, aeroplanes, horses, motorbikes, friendships and games like snooker, some things that "thrust me into manhood". 79 The poem suggests that shared experiences like extended patrols, stand to and actions preceding a first-light attack are similar to those experienced at a football match or a camp. The poem makes note:

Of friendship, almost love

For buddies who ate with you

Laughed

And shat with you, sharing the shivering

Pre-dawn quiet

And your last Lexington. ${ }^{80}$

The poem makes the historic link by referencing: 
... your father's eyes.

Misty with understanding

Of memory shared across the years

Awkward

In his offer of a beer.

And in him too

You recognise

The images of war. ${ }^{81}$

The publication brings the male martial role together when it ends with reference to distant days:

That thrust me into manhood,

Drawing from my heart

The innocence

Of a childhood joy. ${ }^{82}$

The military as a catalyst for entry into manhood appears at the beginning, ${ }^{83}$ at the end ${ }^{84}$ and in the middle. ${ }^{85}$ Like the first and last poem, "Entry into manhood" 86 involves an inner reflection. Unlike the previous two, the third focusses entirely on the development of inner strength. The military as a developer of inner strength also occurs later, as a reflection on "pre-jump tension" $" 87$ in a Dakota before a combat jump, a reflection when paratroops are "poised to jump" 88 and provided with a "Draw [of] the rich tobacco smoke". 89

The natural place of military in society is reinforced by the presentation of things that are experienced. The internal controlling force, the soul of the Discourse, is presented as a paternal force. National service is described by a "him". This male person could have been someone's father, who was conscripted a generation before, or the school cadet officer, a teacher who came to school in military uniform once a week. The paternal force is presented twice, once as a rebellious reflection of a parade:

"Wonderful thing, National Service",

I remember him saying

"teaches one patience, gives you perspective". 90

The second expression of the presence of a paternal force in the military is not limited to indirect social forces. One poem takes a father to the area of operation. $^{91}$

He was, I remember,

A quiet man.

Thick set, taciturn, and dark 
With bull strength, his voice. ${ }^{92}$

Credibility for the father figure is provided through the presentation of emotion. In one case, it is provided by means of satire:

I remember him saying,

As we wait

Here in the sun. ${ }^{93}$

In another case, paternal credibility is provided through tears:

How odd, it seemed, then,

To see him cry,

His son on his shoulders

Saying goodbye. ${ }^{94}$

\section{The portrayal of rituals, processes and routines}

Work done by people is romanticised and framed in a positive manner. There are no dangerous situations, only opportunity for rhythmic reflections, reawakening childhood fantasies and rediscovering meaning. A mounted patrol allows a soldier to:

Close your eyes,

Lose yourself in the slapping

Creaking rhythm of leather ... ${ }^{95}$

Similarly, a foot patrol, ${ }^{96}$ accompanied by a sketch of a shirtless person carrying his webbing in his hand and rifle slung over his shoulder, tells nothing about the patrol; it reflects the sun, heat and images of light. If the equipment and clothing were replaced, the sketch could easily have been that of a young man walking on the beach. A soldier on a mine-proof Buffel troop carrier, similarly, has an opportunity to witness a Kalahari dawn and a "browsing kudu", ${ }^{97}$ not dissimilar to game watching at a nature reserve.

A dangerous, uncomfortable observation post provides an opportunity to reflect on "Childhood fantasy":

... reawakened by this crow's nest,

Stark against the cumulus

That writhes, in a living sculpture.

Above your ship of sandbags

In its sea of drifting dunes. ${ }^{98}$ 
Arduous routines, either added to romance, in the case of both the "mounted patrol" and "crow's nest", or used alone, are framed in a positive textual rhythm. Filling sandbags, which Siegfried Sassoon associated with parapets, rats, stench and death, ${ }^{99}$ is described as a process of "reluctant servitude" 100 in which:

We pour,

Each libation

Distorting

Their hessian tunics, drawing from them

A contented burp

Of dust.

Routine, particularly cleaning, is used to indicate military life as a baptism, rite of passage and a positive developmental life skill. "The ritual"101 asks:

What depth of meaning

Has this ritual,

That transcends the need to clean,

To polish and prepare?

"The ritual" goes into an amount of detail to illustrate the developmental and baptismal nature of the military. After posing a question on verse, it supplies the answer:

\author{
All have done it \\ Who face the test of war \\ Filling the waiting hours with preparation \\ Check and counter-check \\ Hands, in mute rehearsal, \\ Gauging: \\ Testing trigger tension \\ To release their own.
}

The poem ends by likening preparing mortar bombs for firing with a religious process:

For each boy-man,

Encircled by his rosary of glinting shells,

The apprehension dissipates itself

In this final reverie,

The bombs before him,

Solemnly paraded

Before arcing to destruction 
In polished grace.

Females are never mentioned, not with reference to the work they did in providing support services, nor in passing reflection to those at home. The absence of female reference fits the western ideology applied in Southern African at the time, namely that war is no place for women.

\section{The portrayal of friendship and belonging}

A sense of belonging permeates the work. It is portrayed in a variety of situations, including sleeping ${ }^{102}$ and smoking. ${ }^{103}$ It is also expressed in detail when it makes reference to a modern conflict situation's danger, being wounded or killed.

Real comfort exists,

As assurance underwriting risk,

In the knowledge of buddycare,

The world's compound simplicity

Meaning only that:

Care

For friends - buddies - under duress,

Under fire, unto death,

But first,

It's a bond of reciprocity,

A failsafe guarantee

Of life. ${ }^{104}$

In contrast to the physical realities of conflict, this collection provides a failsafe guarantee of life. The guarantee provided to the reader is not linked to medical care; it is linked to generalisations of relationships - care and reciprocity.

\section{The portrayal of conflict}

Conflict is portrayed as the nodal point of a process preceded by preparation and followed by a chase and reaction.

Preparation has an airborne element, ${ }^{105}$ the involvement of equestrian, canine and motorcycle elements, ${ }^{106}$ and a ground-based ambush. ${ }^{107}$ The textual tempo of all these poems, with the exception of the ambush, is rhythmic, with an increasing pitch. In contrast, the tone of the ambush is quiet, with the words "silent" and "patient" preceding the first two verses. The third verse, however, links to the other poems by starting with the word "tensing", and continuing with the indication of orders. In addition to the tempo, this is the only poem that does not feature white 
soldiers; the soldiers are "Zulu soldier[s] from the South African Army's 12 Battalion". 108

The contact presents three images. The first verse presents the foggy nature of battle:

Beyond the clarity of focus

I replay, re-run behind my eyes

Those telescoping seconds,

Each time

Seeming shorter than the last. ${ }^{109}$

The verse also presents the image of those who started the conflict. In the poem, it is a landmine, not an SADF-orchestrated ambush or reactions to apartheid oppression, commonly depicted in struggle literature. ${ }^{110}$ By implication, the ambush says, "they started". The poem also illustrates technological superiority - before the fog of war clears, helicopters and trucks arrive.

The second reflection of combat, although called "return fire" and depicting a member of South West Africa's Specialist Unit's motorcycle section, focusses on the curiosity:

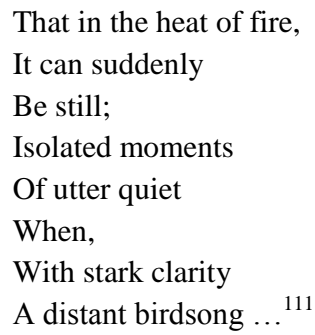

The reflection of a contact ends positively with a casualty evacuation that provides "a failsafe guarantee of life". ${ }^{112}$ The portrayal of conflict is therefore planned, the enemy is allowed to make the first move and, after an amount of fog and haze, there is a positive and definite end.

Three poems that follow the contact ${ }^{113}$ illustrate follow-up operation. "Images of war" indicates how the enemy was followed:

Six days they ran before us dark with the killing and dark with the fear of it. ${ }^{114}$

The poem also indicates that some were killed:

Behind them, silent in death, They left two men, anonymous, broken 
And dark with the killing. ${ }^{115}$

There is a stark contrast between, on the one hand, the enemy's fear and death that leave its members anonymous and broken, and, on the other, the army's "failsafe guarantee of life" and medical attention, ${ }^{116}$ and medical attention to a local child, one of the "Innocents about the fringe, Licked by the tongues of war". The contrast continues with the last few poems, portraying time for troops to reflect on the situation, but leaving the hint that the Bushmen, the "innocents", run the risk of being engulfed "leaving only memories ... of our passing". 117

Positive grammar is used to describe death. Death is mentioned twice: once with reference to a solder, and the second time with reference to the enemy. Colour differentiates the two. The enemy's death was dark but when the South African soldier is shot, the colour illustration used is pink:

Dreamlike, mute,

The tumbling fragments lie beyond

My reason's grasp:

The landmine's signal blast

And the steady rattle through the smoke

Or was it dust?

The wild running chase, lacerated

By the clutching thorn,

Before the shout

That brought me down emptying a magazine

More high than low,

And Van Zyl beside me, standing

Till he spun, spraying pinkness

Across my legs and pack. ${ }^{118}$

The casualty is therefore portrayed as metaphorical and pink. Pink, the pretty colour associated with feminine beauty, is followed by a "failsafe guarantee of life". ${ }^{119}$ The enemy's death is, however, direct, "dark with killing", inevitable, laced with fear and anonymous. Note the following:

Six days they ran before us,

Dark with killing, and fast

With the fear of it.

Closer each dawn

We came, crouched on the spoor

Like hungry dogs, exhaustion

In our shadow. 
And then, at dusk,

We met upon their killing ground,

The dull chatter of their fire

Following the dust

That kicked and stung about us,

There is no measure

Of the time that passed

Before light melted from us,

Cloaking their flight into the sudden black

Webbed

With our tracer.

Behind them, silent in death,

They left two men, anonymous, broken

And dark with killing. ${ }^{120}$

As with death, killing is contrasted positively as "emptying a magazine" and a "web of tracer", with direct negative wording like "their killing ground", "silent in death", "broken" and "dark with killing". Casualties are also contrasted as personal, "Van Zyl", with a "failsafe guarantee of life", with anonymity and being "broken".

\section{The portrayal of the military system}

Throughout the collection, the military is exemplified as a well-oiled machine staffed by well-trained and caring professionals, committed to service, even if the service was not what the characters might have chosen, had they the choice. These references include inferences like national service being described, tongue in cheek, as a "wonderful thing"121 and a "Pump jockey of a different kind ... [who] pours the golden liquid ... injecting life". ${ }^{122}$

Direct, detailed reference is made to the service ethic of the professional leader element and medical support. Badcock refers to a leader in the next extract:

He was, I remember,

A quiet man ...

He said little, though,

Smiling less,

Using his eyes, which were grey,

Like a sjambok. ${ }^{123}$ 
The professional system metaphor is also portrayed in the depiction of conflict. The series depicting the contact cycle from preparation to follow-up operation illustrate the specialist functions available, including paratroops, equestrian units, dog units, motorcycle units and armoured vehicles. It also illustrates the use of blacks in terms of a skewed view of their traditional role - the Zulu skill of ambush and killing and the Bushmen skill at tracking.

The timelessness of the system that spans generations is portrayed through parental approval. $^{124}$

\section{The apartheid military body politic}

Through blank verse and pencil sketches, the moral orthopaedics, ${ }^{125}$ the order of life, the concept which Eco calls "being", ${ }^{126}$ and which Foucault calls "the body politic", 127 expressed in Images of war, is that young whites leave home, mix with other classes of white men, and a sprinkling of men from other races, thereafter returning home to approving male parents.

The collection creates a systemic body of knowledge, using the logic of prose and visual imagery, to gain acceptance of the underlying imagery as an order of life that was the order of life for their fathers and ancestors. In this environment, work not normally done by middle-class young males is done as part of an unwritten growth mechanism. Some roles are martial and others technical, while some of the work is associated with other social classes. The successful implementation of the body politic-created power - knowledge relations between the apartheid military order is subordinate docile soldiers.

The methodology applied in the publication comprises its phonology, grammar and vocabulary, which is either light, positive English or slang characteristic of some races and/or classes identifiable by South Africans. When using light, positive English, it is characteristic of poetry commonly found on popular posters. Badcock also links the use of this type of grammar to African artefacts and geographic references to portray experiences of black Africans. Where he uses slang, reinforced by accompanying sketches, the stereotypes are easily identified as coloured people and lower-class whites.

Race and masculinity are the technologies that incorporate the body politic. The apartheid racial and gender hierarchy is therefore illustrated by a combination of poetic and visual illustrations, grammar, historical analogy and, for the select group, personalisation. White males feature exclusively as elements of military service; people classified as coloured feature as deviants, both through illustrations and by the use of grammar. Blacks feature either as the martial descendants of those who have been defeated, or as confused victims. For Afrikaners, however, the conflict is personal. One casualty even has a name - Van Zyl. ${ }^{128}$ 
Ritual, process and routine are those technologies that integrate the body politic. Rituals and cognitive processes are integrated into the military way of life through analogy between what is done in contexts like childhood imaginary games, wildlife vacation, playing with sand and religious procedures. Friendship and belonging under conditions of adversity while facing enemies are the technologies that cement integration through the portrayal of peace and licence in the midst of conflict. Command service and parental approval are the technologies that link the cemented incorporation to higher author, both within the military system and to the preceding generation.

The technologies employed create a sound body politic. It is logical, positive and realistically believable by those who had experienced apartheid military life.

Positive language is a signature of both Badcock's work and the work of other authors who ventured into positive portrayals of the apartheid way of life. Some other publications were more explicit in portraying the apartheid military discourse while others were indirect, often contextualising their work in service frameworks.

Bertrand Retief's publication followed a similar discourse. ${ }^{129}$ The word "humour" in the title has a U inserted ("Humo"r"), implying thus both the English and Afrikaans spellings of the word, something that was common in apartheid signage. The portrayal of the apartheid military discourse is more direct than that of Badcock. However, Retief's work was written by an army officer who dedicated the book to its conceptualiser, Army head, J Geldenhuys.

Authors like Steenkamp, Morris and Venter, in contrast, wrote documentaries on life in the military based on their experiences as journalists visiting operational areas. Their discourse is light, portraying the ordinariness of life in the military in Portuguese Angola or Mozambique, Rhodesia or South West Africa (Namibia). The surrounding political situation, if mentioned, was framed within the communist onslaught.

De Vries portrayed the soundness of the principles underlying the apartheid military system. ${ }^{130}$ Despite his use of a positive discourse, De Vries makes timeous mention of German actions during World War II. Although the logic of his argument, namely that mechanised warfare is largely based on the blitzkrieg, ${ }^{131}$ is sound, his reference to German action in World War II has a negative discursive element in that it indicates why German tactics had failed.

Other publications portrayed service. Gee gave advice to Christians from a legal positivist perspective, ${ }^{132}$ while Douwlina Grobler's publication, Vereffening, is a novel about a mother coming to terms with the death of her son. ${ }^{133}$ 


\section{The lingering success (and failure) of the apartheid military Discourse}

The expression of the Discourse through language in use and practice in South Africa remains, despite significant social and political changes since the late 1980s. One of the threads that resulted in this analysis was a conversation I had with a colleague, a white male academic and a conscientious objector who refused to serve in the SADF in the late 1980s. Although he had not changed his conviction to refuse to do military service in the 1980 s, he felt that he had missed out on an experience that his peers had.

The expression of the apartheid military discourse is not limited to social reminiscing. Badcock's publication, as well as elements contained in it and its ideology still has market value.

- In December 2007, a copy was sold on Bid or Buy ${ }^{134}$ for R200,00 by a purchaser called Tommy Atkins. ${ }^{135}$ In 2007, the publication was for sale at $\$ 80,00$ on the warstore, a South African website selling a wide variety of military surplus, memorabilia and publications. ${ }^{136}$

- Also in 2007, a poster of "The vigil"137 was available for $\$ 13,95$ from Camping Survival. ${ }^{138}$

- Chas Lotter, publisher of numerous publications on life in the Rhodesian Army was encouraged by Badcock to "write more" and is published from a website of a South African university that served as one of the centres of the anti-apartheid struggle. ${ }^{139}$

There appears to be a growing number of expressions of the apartheid military Discourse being published.

More profound than expressions of the value of military service is the promulgation of Act 27 of 2006, the Prohibition of Mercenary Activities and Regulation of Certain Activities in Country of Armed Conflict. ${ }^{140}$ Security force personnel trained during the apartheid era, "thousands" according to Barlow, ${ }^{141}$ are in service in various parts of the world and their children have volunteered to serve in both the South African armed forces and those of other countries. Through Act 27 of 2006, the state has made foreign military service illegal.

A question that grows out of the analysis presented is, if the apartheid military discourse was so successful in creating more than one generation of soldiers, why it did not maintain the existence of apartheid. Why, on a practical level, did the end of the apartheid war and the incorporation of the SADF into the SANDF (the post-apartheid South African National Defence Force) occur so successfully and why did so many apartheid soldiers voluntarily serve both the apartheid and post-apartheid governments? Similarly, why did its soldiers serve its 
erstwhile enemies through organisations like Executive Outcomes? The answer lies in the subliminal nature of the discourse.

The apartheid military discourse was, using Foucault's terminology, an "artificial order", an order "laid down by law" and a "set of regulations" with "natural observable processes". ${ }^{142}$ This order was, however, rejected by a critical mass of people who were supposed to be subjugated by it. White males rejected the order at an increasing rate, to the extent that when the SADF citizen force was called up for the 1994 election only a fraction reported for duty.

As an order, the apartheid military discourse was not effectively subjugated to its overarching ideology. What, in this article, has been called the "apartheid military discourse", was in reality a professional military discourse that developed professional soldiers and militarised civilians who served a useful purpose for the apartheid cause. However, as the focus was on professionalism and not on the ideology it served, the relationship between the two discourses was coincidental, not causal, allowing the professional military discourse to supersede its intention.

The nature of apartheid's military Discourse - both its success as a professional Discourse and its failure as an ideological Discourse - is starkly illustrated by a recent autobiography of Roy Andersen. At one stage, he was chairperson of the Johannesburg Stock Exchange as well as a colonel in the SADF citizen force, but later the most senior general in the post-apartheid SANDF reserves and director of a number of large South African companies. Andersen says that he "never equated military service in the conventional forces with defending apartheid". 143 He does, however, say he "didn't give the question enough thought" but noted, "I was clear in my own mind that apartheid was morally indefensible". Later, no doubt after he had given it more thought, he became instrumental in contributing to the creating of a post-apartheid stock market, business environment and the military's reserve environment.

By creating a cohort of professional soldiers without the concomitant ideological base, what was created was not merely what Foucault would have called "docile bodies" serving apartheid, but rather a cohort of docile bodies capable of actively transforming the post-apartheid military system.

\section{Conclusion}

Like much of the third world, South Africa has transformed from a colonial social entity to a post-colonial social entity that, on the one hand, expressed an anticolonial ideology and, on the other, oppressed dissention. However, unlike much of the third world, the country has transferred itself with remarkable success from its post-colonial form to a western capitalist democracy. One of the pillars of the country's transformation from the apartheid-based state to a democratic state is the 
military. As the military consisted of a relatively small professional component, supported by a relatively large reserve force element, a key element to success was the maintenance of voluntary support.

Badcock's publication illustrates how support was generated in the early 1980 s, a time when overtly expressed racism would have been an unacceptable rallying cry. Instead of racism, used in both Europe and Africa in the 1930s and again in the 1990s, the apartheid state used an almost invisible discourse that linked its need for docile bodies to masculinity, family genealogy, root metaphors and accepted practice. At the time, the apartheid state would not have gained support for killing blacks. However, it managed to gain support for the idea that military service is good for boys to the extent that not only did thousands of white males voluntarily report for service, but the supply of males from other races outstripped demand. Furthermore, the value of military service was so entrenched in the community at which the information war was aimed that, when national service was abolished, a market developed for what became known as 'gap-year experiences'. Furthermore, in the absence of a route into the South African military, many of the sons of the generation who have done national service are now voluntarily serving in the armed forces of other countries.

\section{Endnotes}

${ }^{1}$ Senior lecturer, Faculty of Education and Social Sciences, Department of Further Education and Training, Cape Peninsula University of Technology.

${ }^{2}$ Badcock, P. Images of war. Durban: Graham, 1981.

${ }^{3}$ Foucault, M. Discipline and punish: The birth of the prison. Harmondsworth: Penguin, 1979.

${ }^{4}$ Fairclough, N. Language and power. Harlow: Longman, 1989; Fairclough, N. (ed), Critical language awareness. London: Longman, 1992; Fairclough, N. Analysing discourse: Textual analysis for social research. New York: Routledge, 2003.

${ }^{5}$ The terms mainstream and alternate were general terms of reference at the time. Mainstream forums included the popular press and publications that complied with the official regulatory framework. Legislation included censorship and, after 1985, restrictions put in place by the state of emergency. Alternate forums included a broad spectrum of formats that were not constrained by apartheid legislation, either in defiance of the law or by publication occurring outside the country's borders.

${ }^{6}$ De Vries, R. Mobiele oorlogvoering: 'n Perspektief vir Suider-Afrika. Menlopark: FJN Harmon, 1987; Gee, RK. Bugles, bayonets and believers. Cape Town: 
SAYFC Literature, 1974; Grobler, D. Vereffening. Pretoria: Femina, 1981;

Retief, B. Humour in SA uniform. Johannesburg: Perskor, 1991.

${ }^{7}$ Foucault, op. cit.

${ }^{8}$ Maclure, M. Discourse in educational and social research. London: Open University Press, 2003.

${ }^{9}$ Ibid.

${ }^{10}$ Fairclough, Language and power, op. cit.; Fairclough, Critical language awareness, op. cit.; Fairclough, Analysing discourse, op. cit.

${ }^{11}$ Henning, E. Finding your way in qualitative research. Pretoria: Van Schaik, 2004; Maclure, op. cit.

${ }^{12}$ Fairclough, Critical language awareness, op. cit. p. 8.

${ }^{13}$ Fairclough, Language and power, op. cit. p. 109.

${ }^{14}$ Maclure, op. cit.

${ }^{15}$ Ibid.

16 Ibid.

${ }^{17}$ Fairclough, Critical language awareness, op. cit. pp. 8-9.

${ }^{18}$ Fairclough, Language and power, op. cit. p. 109; Fairclough, Critical language awareness, op. cit. pp. 7-8.

${ }^{19}$ Deacon, R. Michel Foucault on education: A preliminary theoretical overview. South African Journal of Education 26/2. 2006. 177.

${ }^{20}$ Foucault, op. cit.

${ }^{21}$ Ibid. p. 10.

${ }^{22}$ Ibid. p. 28.

${ }^{23}$ Ibid. p. 27.

${ }^{24}$ Ibid. p. 179.

${ }^{25}$ Ibid. pp. 16-26.

${ }^{26}$ Fairclough, Language and power, op. cit.

${ }^{27}$ Ibid. p. 141.

28 Ibid.

29 Ibid.

${ }^{30}$ Fairclough, Critical language awareness, op. cit.; Fairclough, Analysing discourse, op. cit.

${ }^{31}$ Maclure, op. cit.

${ }^{32}$ Henning, op. cit.

33 Ibid.

${ }^{34}$ Fairclough, Analysing discourse, op. cit.

${ }^{35}$ Gerhart, GM. Black power in South Africa. Berkley: University of California Press, 1979; Johnson, RW. How long will South Africa survive? 
Johannesburg: Braamfontein, 1977; Lodge, T. Black politics in South Africa since 1945. Johannesburg: Ravan Press, 1983.

${ }^{36}$ The body only becomes a socially useful social force, a productive body, when it has been subjugated to social relations of power and dominance (Foucault, op. cit. pp. 25-26).

${ }^{37}$ Foucault, op. cit.

${ }^{38}$ Tomlinson, R \& Addleson, M. Regional restructuring under apartheid: Urban and regional policies in contemporary South Africa. Johannesburg: Ravan Press, 1987.

${ }^{39}$ Foucault, op. cit. p. 10.

40 'Moral orthopedics' refers to correction or prevention of disorders to the soul, the individual's mental and psychic composition, through repetitive therapeutic treatment (Hook, D, Mkhize, N, Kiguwa, P, Peace, K \& Collins, A. Critical psychology. Cape Town: UCT Press, 2007, 218).

${ }^{41}$ These three publications are mentioned as illustration. Many more can still be found in bookstores and in public libraries.

${ }^{42}$ Grobler, op. cit.; Retief, op. cit.

${ }^{43}$ De Vries, op. cit.; Steenkamp, W. Adeus Angola. Cape Town: Howard Timmins, 1976.

${ }^{44}$ Eco, U. Kant and the Platypus. Random House: Vintage, 2000.

${ }^{45}$ D'Este, C. A genius for war. London: Harper Collins, 1995, 237-239; 697.

${ }^{46}$ Badcock, op. cit.

${ }^{47}$ Fredericks, J. None but ourselves: Masses vs media in the making of Zimbabwe. Johannesburg: Ravan Press, 1982, 150-198.

${ }^{48}$ Badcock, op. cit. p. 112.

${ }^{49}$ Ibid. pp. 107-111.

${ }^{50}$ Ibid. pp. 20; 58; 80.

${ }^{51}$ Ibid. pp. 16; 44.

${ }^{52}$ Ibid. pp. 22, 30.

${ }^{53}$ Ibid. p. 80.

${ }^{54}$ Ibid. p. 16.

${ }^{55}$ Ibid. pp. $23-25$.

${ }^{56}$ Ibid. p. 32.

${ }^{57}$ Ibid. p. 28.

${ }^{58}$ Ibid. p. 34.

${ }^{59}$ Ibid. p. 36

${ }^{60}$ Ibid. p. 29.

${ }^{61}$ Ibid. p. 35. 
${ }^{62}$ Ibid. p. 37.

${ }^{63}$ Ibid. p. 17.

${ }^{64}$ Ibid. p. 45.

${ }^{65}$ Ibid. p. 16.

${ }^{66}$ Ibid. p. 44.

${ }^{67}$ His trousers are rolled up to just below his knee and his shirt appears not to be buttoned correctly.

${ }^{68}$ Badcock, op. cit. p. 20.

${ }^{69}$ Ibid. p. 58.

${ }^{70}$ Ibid. p. 58.

${ }^{71}$ Montgomery of Alamein. A concise history of warfare. London: Collins, 1972, 266.

${ }^{72}$ Badcock, op. cit. p. 80.

${ }^{73}$ Ibid. p. 32.

${ }^{74}$ Ibid. p. 52.

${ }^{75}$ More detail on the horse breed used is provided later (Badcock, op. cit. p. 93). In the explanation of the horses, the Rhodesian link, and by implication the author's authority, to the type of war is made. It is also noted on page 93 that the 'favoured' saddle is the Rhodesian-developed McClellan saddle - the passing mention that the Rhodesians knew what was best for the situation at hand.

${ }^{76}$ Badcock, op. cit. p. 52.

${ }^{77}$ Ibid. p. 66.

${ }^{78}$ Ibid. p. 112.

${ }^{79}$ Ibid. p. 112.

${ }^{80}$ Ibid. p. 10.

${ }^{81}$ Ibid. p. 112.

${ }^{82}$ Ibid. p. 112.

${ }^{83}$ Ibid. p. 11.

${ }^{84}$ Ibid. p. 112.

${ }^{85}$ Ibid. p. 48.

${ }^{86}$ Ibid. p. 46.

${ }^{87}$ Ibid. p. 54.

${ }^{88}$ Ibid. p. 60.

${ }^{89}$ Ibid. p. 76.

${ }^{90}$ Ibid. p. 12.

${ }^{91}$ Ibid. pp. 26-27.

${ }^{92}$ Ibid. p. 26. 
${ }^{93}$ Ibid. p. 12.

${ }^{94}$ Ibid. p. 26.

${ }^{95}$ Ibid. p. 14.

${ }^{96}$ Ibid. p. 42.

${ }^{97}$ Ibid. pp. 82-83.

${ }^{98}$ Ibid. p. 36.

${ }^{99}$ Clapman, M. First World War poetry. Hertfordshire: Wordsworth, 1995, 97; 103.

${ }^{100}$ Badcock, op. cit. p. 18.

${ }^{101}$ Ibid. p. 28.

${ }^{102}$ Ibid. p. 38.

${ }^{103}$ Ibid. pp. 10; 76.

${ }^{104}$ Ibid. p. 70.

105 Ibid. pp. 50; 54; 60; 64.

${ }^{106}$ Ibid. pp. 52; 62; 68.

${ }^{107}$ Ibid. p. 58.

${ }^{108}$ Ibid. p. 95.

${ }^{109}$ Ibid. p. 66.

${ }^{110}$ Gerhart, op. cit.; International Defence and Aid Fund. Apartheid's army in Namibia. London, 1982.

${ }^{111}$ Badcock, op. cit. p. 68.

112 Ibid. p. 70.

${ }^{113}$ Ibid. pp. 74; 76; 78.

${ }^{114}$ Ibid. p. 74.

115 Ibid. p. 74.

${ }^{116}$ Ibid. p. 78.

${ }^{117}$ Ibid. p. 80.

${ }^{118}$ Ibid. p. 66.

${ }^{119}$ Ibid. p. 70.

${ }^{120}$ Ibid. p. 74.

${ }^{121}$ Ibid. p. 12.

${ }^{122}$ Ibid. p. 34.

${ }^{123}$ Ibid. p. 26.

${ }^{124}$ Ibid. p. 112.

${ }^{125}$ Foucault, op. cit. p. 20.

${ }^{126}$ Eco, op. cit. p. 12.

${ }^{127}$ Foucault, op, cit. p. 28.

${ }^{128}$ Badcock, op. cit. p. 66.

${ }^{129}$ Retief, op. cit. 
${ }^{130}$ De Vries, op. cit.

${ }^{131}$ De Vries, op. cit. p. 38.

132 Gee, op. cit.

${ }^{133}$ Grobler, op. cit.

${ }^{134}$ Bidorbuy. Bidorbuy.co.za: Africa's largest online marketplace. 2007. <http://www.bidorbuy.co.za/jsp/item/Item.jsp?Trade_TradeId=1851280> Accessed on 27 May 2011.

135 Tommy Atkins is no doubt a pseudonym. It is the name used by the popular British press since the mid-nineteenth century to name the average soldier.

${ }^{136}$ Warstore. All wars - books. 2007. <http://www.warstore.co.za/ALLBG.asp?ItemID=5> Accessed on 27 May 2011.

${ }^{137}$ Badcock, op. cit. p. 32.

${ }^{138}$ Campingsurvival. Camping survival. 2007. <http://www.campingsurvival.com/senpetbadpri.html> Accessed on 27 May 2011.

${ }^{139}$ University of the Western Cape. Chas Lotter's war poetry. 2007. <http://www.uwc.ac.za/arts/bushvibes/chaslotter/chasinterview.html> Accessed on 27 May 2011.

${ }^{140}$ South Africa. Prohibition of Mercenary Activities and Regulations of Certain Activities in Country of Armed Conflict Act 27 of 2006. 2007. Government Gazette 509(30477).

${ }^{141}$ Barlow, E. Executive outcomes. Alberton: Galago, 2007, 527.

${ }^{142}$ Foucault, op. cit. p. 179.

${ }^{143}$ Andersen, R. Commanding heights. Rosebank: Penguin, 2006, 7. 